\title{
IDENTIFIKASI MOLEKULER BAKTERI ENDOFIT MANGROVE Rizhopora mucronata PENGHASIL GELATINASE (MMP $\left.{ }_{2}\right)$
}

\author{
Happy Nursyam, Asep Awaludin Prihanto* \\ Program Studi Teknologi Hasil Perikanan, Fakultas Perikanan dan Ilmu Kelautan, Universitas Brawijaya, \\ Malang \\ Jalan Veteran Malang 65145, Jawa Timur- Indonesia \\ Telepon 0341-553512; Faks. 0341-557887 \\ *Korespondensi: asep_awa@ub.ac.id \\ Diterima: 20 September 2017/ Disetujui: 11 Mei 2018
}

Cara sitasi: Nursyam H, Prihanto AA. Identifikasi molekuler bakteri endofit mangrove Rizhopora mucronata penghasil gelatinase $\left(\mathrm{MMP}_{2}\right)$. Jurnal Pengolahan Hasil Perikanan Indonesia. 21(1): 143-147.

\begin{abstract}
Abstrak
Gelatinase adalah salah satu jenis keberagaman dari kelompok protease. Enzim metallo-endopeptidase ekstraseluler atau metaloproteinase mampu menghidrolisis gelatin. Enzim gelatinase menghidrolisis gelatin menjadi hidrolisat gelatin. Penelitian ini bertujuan mengisolasi bakteri endofit yang menghasilkan enzim gelatinase yang dapat dimanfaatkan untuk keperluan industri. Penelitian ini dilakukan dengan beberapa tahapan yaitu pengambilan dan preparasi sampel, skrinning gelatinase, seleksi strain potensial penghasil enzim gelatinase, dan analisis spesies menggunakan sekuensing $16 \mathrm{~S}$ rDNA spesies bakteri. Hasil penelitian menunjukkan bahwa isolat dari bagian daun mangrove menunjukkan aktivitas enzim gelatinase yang tinggi dengan kode isolat CL-h4. Analisis sekuen $16 \mathrm{~S}$ rDNA menunjukkan isolat memiliki kemiripan dengan Enterobacter hormaechei N6. Pohon filogenetik menunjukkan bakteri Enterobacter sp. $U B-R^{\star *}$ berada pada satu cabang maupun node (genus) yang sama dengan bakteri Enterobacter sp. dengan nilai boostrap sebesar 0,6. Mikroorganisme endofit mangrove penghasil enzim gelatinase $\left(\mathrm{MMP}_{2}\right)$ dari daun mangrove Rizhopora mucronata adalah strain baru Enterobacter sp. UB-R.
\end{abstract}

Kata kunci: endofit mangrove, Enterobacter sp. UB-R, gelatinase, mikroorganisme, penapisan

\section{Screening of Mangrove, Rizhopora mucronata Endophytic bacteria which capable of producing Gelatinase (MMP $\left.{ }_{2}\right)$}

\begin{abstract}
Gelatinase is one protease superfamily group, an extracellular metallo-endopeptidase or a metaloproteinase which capable of hydrolyzing gelatin. This enzyme can be used for producing gelatin hydrolysate. This study aimed to isolate endophytic bacteria producing gelatinase enzymes for industrial purposes. This research was conducted with several stages, namely sample preparation, screening gelatinase, selection of potential gelatinase-producing strains, and analysis of species using $16 \mathrm{~S}$ rDNA. Bacteria from mangrove leaf showed highest gelatinase enzyme activity with code of CL-h4. Sequence analysis of $16 \mathrm{~S}$ rDNA showed that the isolate had similarities with Enterobacter sp. The phylogenetic tree revealed that bacteria Enterobacter sp. UB-R was in one branch and the same node (genus) with Enterobacter hormaechei N6 bacteria, with a boostrap value of 0.6. Endophytic mangrove isolated from Rizhopora mucronata leaf which produced gelatinase (MMP2) was a new strain called Enterobacter sp. UB-R
\end{abstract}

Keywords: gelatinase, mangrove endophytic, screening, microorganisms, Enterobacter sp. UB-R.

\section{PENDAHULUAN}

Gelatinase adalah kelompok protease yang termasuk dalam metaloprotein ekstraselular atau metaloproteinase yang mampu menghidrolisis gelatin dan senyawa lainnya misalnya feromon, kolagen, kasein dan fibrinogen. Gelatinase merupakan enzim penting yang penggunaanya tidak hanya pada industri kimia dan kedokteran saja, tetapi juga dalam bidang pangan dan ilmu biologi (Boran dan Regenstein 2010). Gelatinase dibagi menjadi dua tipe yaitu Gelatinase A (MMP-2) dan Gelatinase B (MMP-9) (Xin et al. 2015). MMP-2 dan MMP-9 dikenal pertama kali 
sebagai kolagenase tipe IV berdasarkan pada aktivitasnya yang berlawanan dengan kolagen tipe IV pada membran. Enzim gelatinase yang berasal dari mikroorganisme mampu menghidrolisis gelatin menjadi komponenkomponen seperti polipeptida, peptida, dan asam amino. Bakteri-bakteri di antaranya Pseudomonas aeruginosa, Staphylococcus aureus, Clostridium perfringens dan Serratia marcescens diketahui mampu menghasilkan enzim gelatinase.

Mikroorganisme endofit mangrove dilaporkan dapat memproduksi metabolit unik dan berguna untuk keperluan industri sehingga berpotensi untuk diisolasi sebagai penghasil gelatinase. Mikroorganisme endofit merupakan organisme hidup berukuran mikroskopis (bakteri dan jamur) yang hidup dalam jaringan tanaman (xylem dan phloem) daun, akar, buah, dan batang. Bakteri endofitik adalah bakteri yang berada di dalam jaringan tanaman tanpa merugikannya secara substansial (Christina et al. 2013). Bakteri endofit ditemukan pada hampir semua jenis tanaman. Penelitian pada keragaman bakteri endofit mangrove menunjukkan bahwa tumbuhan mangrove merupakan sumber yang kaya bakteri endofit. Bakteribateri yang telah berhasil diisolasi adalah Enterobacter, Pseudomonas, Burkholderia, Bacillus dan Azospirillum (Ryan et al. 2008; Reinhold-Hurek dan Hurek 2011 ).

Enzim gelatinase pada akhir-akhir ini mendapat banyak perhatian sebagai target pengembangan obat karena potensinya sebagai penghantar obat obatan dan bioaktif (Foox dan Zilberman 2015). Gelatin juga dapat digunakan sebagai bahan pembuatan hidrolisat gelatin yang mempunyai berbagai bioaktivitas, salah satu cara untuk membuat hidrolisat gelatin adalah dengan menggunakan enzim gelatinase.

Potensi gelatinase untuk menghasilkan produk hidrolisat gelatin, meningkatkan permintaan enzim ini. Hal ini mendorong peneliti untuk menemukan strain bakteri baru yang menghasilkan enzim dengan sifat baru. Tujuan dari penelitian ini adalah mengisolasi bakteri endofit yang menghasilkan enzim gelatinase yang dapat dimanfaatkan untuk keperluan industri.

\section{BAHAN DAN METODE Bahan dan Alat}

Bahan yang digunakan pada penelitian ini yaitu media LBA, media gelatin, agar, $\mathrm{HCl} \mathrm{HgCl}_{2}$, semua bahan kimia dan media mikrobiologi didapatkan dari Sigma-Aldrich, Jerman. PCR-kit rd 27F (5'-AGAGTTTGATCATGGCTCAG-3'), Primer reverse 1492R (5'-TACGGCTACCTTGTTACGA-3').

Alat yang digunakan pada penelitian ini yaitu cawan petri, Inkubator (Memmert, Jerman), Refrigerator, mesin PCR (Biorad, USA), DNA extraction kit (Promega, USA), software BioEdit, dan ABIPRISM ${ }^{\oplus} 310$ Genetic Analyzer (Thermo Fisher, USA).

\section{Metode Penelitian \\ Pengambilan dan persiapan sampel}

Sampel diambil dari mangrove Avicennia alba di Pantai Sendangbiru, Malang, Jawa Timur menggunakan pisau steril. Bagian mangrove yang dipakai sebagai sampel adalah bagian akar, batang dan daun. Sampel dipindahkan ke kantong steril dan dibawa segera ke laboratorium dalam kotak es untuk mempertahankan suhu pada $4^{\circ} \mathrm{C}$ sehingga dapat digunakan untuk penelitian lebih lanjut.

\section{Penanaman mikroorganisme}

Kultur bakteri mengacu pada Pradhan etal. (2013) dengan sedikit modifikasi. Sampel diencerkan secara bertingkat $\left(10^{-3}-10^{-5}\right)$, dan tiap sampel ditumbuhkan pada media LBA yang mengandung $3 \mathrm{~g} / \mathrm{mL}$ peptone, $1,5 \mathrm{~g} / \mathrm{mL}$ yeast extract, $4,5 \mathrm{~g} / \mathrm{mL}$ agar, $3 \mathrm{~g} / \mathrm{mL} \mathrm{NaCl}$ dan diinkubasi selama 24-48 jam pada suhu $37^{\circ} \mathrm{C}$. Tiap koloni dilakukan pemurnian dengan menggunakan metode streak kuadran. Kultur murni pada suhu $4^{\circ} \mathrm{C}$ disimpan sampai pengujian selanjutnya.

\section{Skrining gelatinase}

Setelah masa inkubasi, koloni bakteri diamati pada agar plate gelatin. Penapisan gelatinase dilakukan mengikuti metode Balan et al. (2012), secara kualitatif dengan melihat pembentukan liquid dilakukan penanaman mikroba pada gelatin agar semisolid $(7,5 \mathrm{~g} / \mathrm{L})$, setelah kultur dua hari, media dimasukkan kedalam lemari es dengan 
suhu $4^{\circ} \mathrm{C}$. Hidolisis gelatin ditandai dengan masih encernya media setelah dilakukan proses pembekuan.

\section{Seleksi strain potensial dengan enzim}

Seleksi tahap dua dilakukan untuk pemeriksaan selanjutnya. Metode semi kauntitatif menggunakan plate Nutrient Agar dengan $0,4 \%$ gelatin mengacu pada metode (Hamza et al. 2006), setelah diinkubasi selama 2-4 hari pada suhu optimal, kemudian sel bakteri digores sebagai satu garis di tengah cawan, media ditambahakan larutan $\mathrm{HCl}-$ $15 \% \mathrm{HgCl}_{2} 10 \%$. Zona yang jelas di sekitar pertumbuhan bakteri ditunjukkan pada aktivitas gelatinase.

\section{Identifikasi bakteri menggunakan sekuensing 16s rDNA}

Tahap awal analisis 16S-rRNA dilakukan dengan mengisolasi DNA genom dari bakteri terpilih yang selanjutnya dilakukan amplifikasi dengan teknik PCR. Sampel DNA yang telah diisolasi sebanyak $1 \mu \mathrm{L}$ dilarutkan dalam campuran berisi 18,5 $\mu \mathrm{L}$ Molecular Water (MW), 2,5 $\mu \mathrm{L}$ Bufer B with Mg2+ 10X, $1 \mu \mathrm{L}$ dNTPs, $1 \mu \mathrm{L}$ primer forward, $1 \mu \mathrm{L}$ primer reverse dan $0,2 \mu \mathrm{L}$ Taq polymerase. Campuran tersebut kemudian dimasukkan dalam mesin PCR, proesesnya diawali dengan denaturasi pada suhu $94^{\circ} \mathrm{C}$ selama 45 detik, annealing pada $61^{\circ} \mathrm{C}$ selama 45 detik, dan suhu pemanjangan $72^{\circ} \mathrm{C}$ selama 2 menit. Program ini dilakukan sebanyak 35 siklus. Proses PCR diakhiri dengan pemanjangan akhir pada suhu $72^{\circ} \mathrm{C}$ selama 10 menit. Hasil amplifikasi diverifikasi dengan elektroforesis gel agarosa $1 \%$ dengan tegangan 110 volt selama 25 menit. Pita DNA yang terbentuk kemudian dibandingkan dengan marker.

Tahap selanjutnya adalah pemurnian hasil PCR menggunakan DNA fagment extraction kit. Hasil PCR yang telah dimurnikan ditambah dengan larutan buffer khusus yaitu $\mathrm{Hi}-\mathrm{Di}^{\mathrm{TM}}$ Formamide (Genetic Analysis Grade-Applied Biosystem) dan disekuensing menggunakan ABIPRISM ${ }^{\circ}$ 310 Genetic Analyzer di Laboraturium Genetika, Jurusan Biologi Fakultas Sains dan
Teknologi, Universitas Islam Negeri Maulana Malik Ibrahim Malang. Hasil sekuensing digunakan untuk mengetahui kemiripan sekuen DNA dengan sekuen DNA bakteri lain yang ada pada GenBank menggunakan bantuan progam Basic Local Alignment Search Tool (BLAST) di situs http://www.ncbi.nlm. nih.gov. Kekerabatan bakteri disajikan dalam bentuk gambar pohon filogenenetik yang dibuat dengan batuan program Phylogeny. fr. Program ini tersedia di situs http://www. phylogeny.fr

\section{HASIL DAN PEMBAHASAN}

Hasil analisis menunjukkan bahwa bakteri endofit mangrove dapat diisolasi dari semua bagian mangrove yaitu akar, batang dan daun. Aktivitas gelatinase tidak ditunjukkan pada semua isolat, hanya pada bagian daun dan batang telah ditemukan bakteri gelatinase (Tabel 1). Hasil analis menunjukkan bahwa mikroba yang ditemukan pada bagian daun menunjukkan aktivitas enzim gelatinase yang tertinggi dengan kode isolat CL-h4. Bagian daun mangrove merupakan bagian yang banyak ditemukan mikroorganisme endofit. Hal ini sesuai dengan temuan Prihanto et al. (2011) bahwa pada bagian daun banyak ditemukan mikroorganisme. Penemuan bakteri penghasil gelatinase pada endofit mangrove ini belum pernah dilaporkan sebelumnya. Sehingga sangat menarik untuk dilakukan eksplorasi lebih lanjut.

Penghasil gelatinase terbaik, yang ditandai dengan semakin encernya media setelah didinginkan selanjutnya dilakukan identifikasi spesies menggunakan teknik molekuler 16s rDNA. Bakteri dengan kode CL-h4 selanjutnya dilakukan isolasi total genom untuk identifikasi spesiesnya.

Hasil isolasi DNA genom bakteri isolat CL-h4 didapatkan sebesar 10100 bp (Gambar 1). Ukuran DNA genom suatu organisme sangat bervariasi tergantung pada mikroorganisme tersebut. Organisme prokariot umumnya memiliki genom yang lebih kecil, baik pada pasangan basanya maupun jumlah gennya dibandingkan organisme eukariot. Gen penyandi 16S-rRNA yang berada pada DNA genom isolat 
Tabel 1 Aktivitas enzim gelatinase pada bagian tumbuhan mangrove (Table 1 Activity of gelatinase enzyme on the part of mangrove plant)

\begin{tabular}{ccc}
\hline \multirow{2}{*}{ Analisis } & \multicolumn{2}{c}{ Bagian Tumbuhan/ Part of the Plant } \\
\cline { 2 - 3 } & Daun/ Leaf & Batang/Stem \\
\hline $\begin{array}{c}\text { Kode isolat/ } \\
\text { code isolates }\end{array}$ & CL-h4 ${ }^{*}$ & M.D.NA-9 \\
$\begin{array}{c}\text { Aktivitas enzim gelatinase/ } \\
\text { gelatinase enzyme activity }\end{array}$ & ++ & + \\
\hline
\end{tabular}

Keterangan:

* $\quad$ : dilanjutkan ke analisis spesies

$+\quad$ : aktivitas gelatinase rendah (media semi solid)

$+\quad$ : aktivitas gelatinase tinggi (media cair)
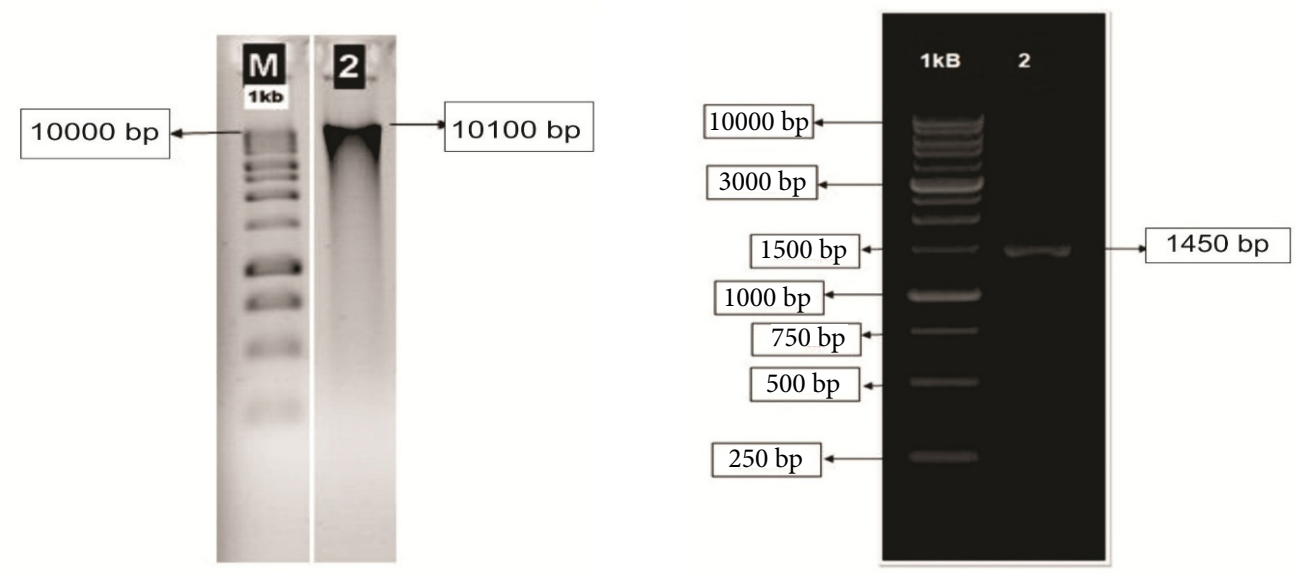

Gambar 1 Hasil isolasi DNA genom bakteri (a) sebelum pemurnian (b) setelah pemurnian (Figure 1 isolation of bacterial genomic DNA (a) before purification (b) after purification)

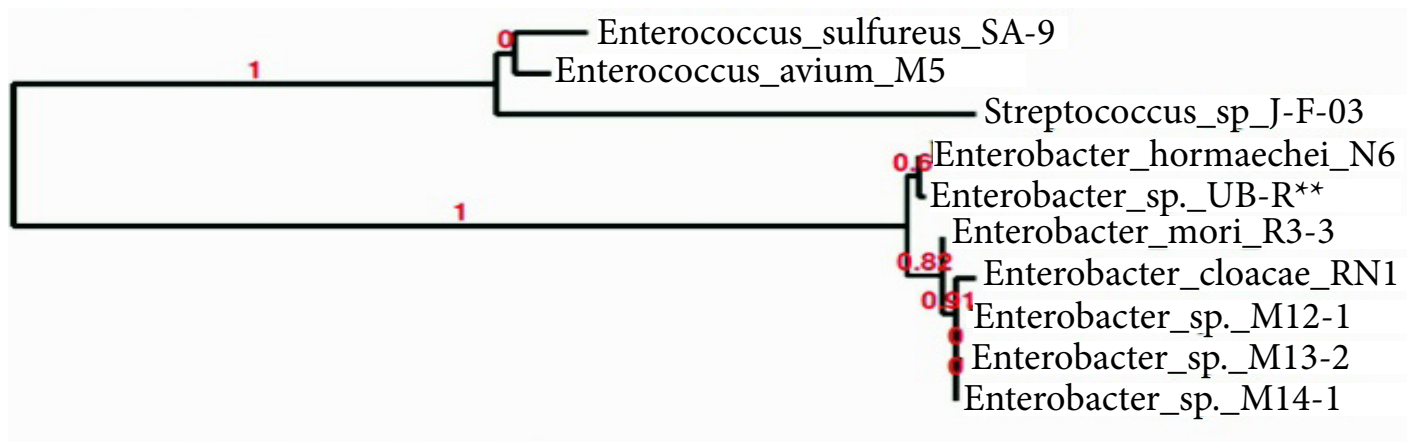

0.1

Gambar 2 Pohon Filogenetik isolat genom bakteri

(Figure 2 Tree Phylogenetic isolates of bacterial genomes)

berhasil diamplifikasi dengan PCR. Produk PCR yang dihasilkan dari elektroforesis amplifikasi DNA berukuran $1450 \mathrm{pb}$.

Hasil sekuensing dari masingmasing primer forward dan reverse, selanjutnya dilakukan penggabungan dengan merubah hasil sekuensing reverse untuk dilakukan pembalikan berpasangan (reverse complement). Urutan basa yang diperoleh dari hasil sekuensing selanjutnya digabungkan dan dianalisis dengan program BLAST. Hasil analisis sekuen 16S rRNA 
menggunakan pogram BLAST menunjukkan isolat memiliki kemiripan 99\% dengan Enterobacter hormaechei N6 (Gambar 2).

Hasil analisis pohon filogenetik jarak genetik (neighbor joining) dapat dilihat pada Gambar 2. Angka yang terdapat disetiap cabang pohon memperlihatkan nilai bootstrap. Berdasarkan pohon filogenetik yang mengikutsertakan beberapa data sekuen GenBank sebagai pembanding menunjukkan bahwa bakteri Enterobacter sp. $U B-R^{* *}$ berada pada satu cabang maupun node (genus) yang sama dengan bakteri Enterobacter hormaechei N6, dengan nilai boostrap sebesar 0,6.

Enterobacter sp. adalah genus bakteri berbentuk basil gram negatif. Kapsul dari bakteri ini cenderung lebih kecil dan ireguler. Kultur bakteri ini memberikan hasil yang baik bila pada kultur dilakukan inkubasi pada suhu $30-37^{\circ} \mathrm{C}$. Kebanyakan bakteri dengan genus Enterobacter memiliki hasil positif untuk pemeriksaan sitrat, motil, dan memproduksi gas dari glukosa namun banyak dari bakteri ini juga memiliki hasil negatif pada uji $\mathrm{H}_{2} \mathrm{~S}$. Organisme ini diketahui dapat mengakibatkan infeksi nosokomial, seperti pneumonia, infeksi pada luka, infeksi saluran kemih, dan infeksi yang diperantarai alat (Brooks et al. 2010), oleh karena itu, penggunaan bakteri ini sebagai penghasil enzim untuk keperluan proses produksi gelatinase perlu untuk dipertimbangkan.

\section{KESIMPULAN}

Mikroorganisme endofit mangrove penghasil enzim gelatinase (MMP2) dengan aktivitas enzim gelatinase tinggi yang diisolasi dari sampel daun mangrove Rizhopora mucronata adalah Enterobacter sp. UB-R.

\section{UCAPAN TERIMA KASIH}

Penelitian ini didanai oleh dana penelitian PTUPT DIKTI tahun 2017 melalui Universitas Brawijaya dengan No kontrak 063/SP2H/LT/ DRPM/IV/2017.

\section{DAFTAR PUSTAKA}

Balan SS, Nethaji R, Sankar S, Jayalakshmi S. 2012. Production of gelatinase enzyme from Bacillus spp isolated from the sediment sample of Porto Novo Coastal sites Asian Pacific. Journal of Tropical Biomedicine. S1811-S1816.

Boran G, Regenstein JM. 2010. Fish gelatin. Advanced of Food Nutrition Research. 60: 119-143.

Brooks GF, Carroll KC, Butel JS, Morse SA, Mietzner TA. Jawetz, Melnick, Adelberg's Medical Microbiology. 2010. In: Adityaputri A, editor. Jawetz, Melnick, \& Adelberg Mikrobiologi kedokteran (25th ed). Jakarta (ID): EGC.

Christina A, Christapher V, Bhore SJ. 2013. Endophytic bacteria as a source of novel antibiotics: An overview. Pharmacognosy Review. 7(13): 11-16.

Foox M, Zilberman M. 2015. Drug delivery from gelatin-based systems. Expert Opinion on Drug Delivery. 12(9): 15471563.

Hamza HM, Ali SM, Hassan HG. 2006. Partial purification of gelatinase enzyme from Local Isolate of Brevibacillus laterosporus. National Journal of Chemistry. 23: 437442.

Pradhan B, Dash SK, Sahoo S. 2013. Screening and characterization of extracelluar $\mathrm{L}$-asparaginase producing Bacillus subtilis strain hswx88, isolated from Taptapani hotspring of Odisha, India. Asian Pacific Journal of Tropical Biomedicine. 3(12): 936-941.

Prihanto AA, Firdaus M, Nurdiani R. 2011. Endophytic fungi isolated from mangrove (Rhyzopora mucronata) and its antibacterial activity on Staphylococcus aureus and Escherichia coli. Journal of Food Science and Engineering. 1: 386-389.

Reinhold-Hurek B, Hurek T. 2011. Living inside plants: bacterial endophytes. Current Opinion of Plant Biology.14(4): 435-443.

Ryan RP, Germaine K, Franks A, Ryan DJ, Dowling DN. 2008. Bacterial endophytes: recent developments and applications. FEMS Microbiology Letters. 278: 1-9.

Xin L, Hou Q, Xiong Q, Ding X. 2015. Association between matrix metalloproteinase-2 and matrix metalloproteinase- 9 polymorphisms and 